\title{
Cikkismertetés: A megelőzés a legjobb befektetés?
}

\section{Article review: Is the prevention the best investment?}

\author{
Ismertető: $\quad$ Berényi Károly $\bowtie$ \\ Pécsi Tudományegyetem Általános Orvostudományi Kar, \\ Orvosi Népegészségtani Intézet, Pécs
}

\begin{abstract}
Ismertetett cikk: Rebecca Masters, Elspeth Anwar, Brendan Collins, Richard Cookson, Simon Capewell: Return on investment of public health interventions: a systematic review. J Epidemiol Community Health 2017;71:827-834.
\end{abstract}

Beküldve: $\quad$ 2019. 11. 05.

doi: $\quad$ 10.24365/ef.v61i2.530

Kulcsszavak: népegészségügy; megtérülés; költség-haszon arány

Keywords: public health; return on investment; cost-benefit ratio

\section{„EGY UNCIÁNYI MEGELŐZÉS FELÉR EGY FONT GYÓGYÍTÁSSAL"}

(Benjamin Franklin)

A cikk szerzői felhívják a figyelmet arra, hogy a magas jövedelmű országokban az állami szektor megszorító intézkedései a népegészségügyi kiadásokat is jelentősen érintik. Mindez annak ellenére történik, hogy még közgazdaságtani számításokkal is alátámaszthatóan ez legtöbbször nagyon jó, pénzügyileg is nyereséges befektetés. Irodalmi áttekintő tanulmányuk e költségcsökkentő intézkedések lehetséges hatásairól kívánnak pontosabb információt nyújtani.

A szerzők által elemzett közlemények két gazdasági mutatószámot használtak: a megtérülési rátát és a költség-haszon arányt.

Megtérülési ráta (ROI - return on investment) alatt a beruházás hasznának és költségének a különbségét értjük a költség arányában kifejezve (későbbiekben: „megtérülés”), míg költség-haszon arány
(CBR - cost benefit ratio) alatt a haszon és a költség hányadosát (ROI = CBR-1) (későbbiekben együttesen: „gazdaságosság”).

A szerzők által elemzett közlemények a következő országok, illetve régiók népegészségügyi intézkedéseinek gazdaságosságát vizsgálták: Egyesült Királyság, Nyugat-Európa országai, Egyesült Államok, Kanada, Japán, Ausztrália és Új-Zéland. A folyóiratok kereséséhez a pubMed, MEDLINE, Scopus, CINAHL, Cohrane, Psyclnfo és AMED adatbázisait használták elsődlegesen, továbbá a Google-t is igénybe vették. Végül 52 cikk eredményeinek elemzését dolgozták fel.

Az elemzések során azt találták, hogy a megtérülés medián értéke 14,3 volt (szemléző: vagyis az ebben a csoportban elemzett kutatások felében minden egyes népegészségügyre fordított forint a költség megtérülésén felül 14,3 forint - vagy annál több hasznot termelt). A költség-haszon arány (CBR) mediánja 8,3 volt (szemléző: minden elköltött forint az ebben a csoportban elemzett cikkek felében 
8,3 forint - vagy ennél magasabb - bevételt, vagyis 7,3 forint hasznot termelt).

(Szemléző: ezt legegyszerübben úgy képzelhetjük el, hogy ha a megtakarításainkból 1 millió forintot a bank helyett népegészségügyi intézkedésre fordítunk, akkor intézkedéstöl függően néhány hónaptól egy-másfél évtizedig terjedő időintervallumban átlagosan 7-14 millió forintot fogunk kapni. Összehasonlításképp ugyanezt a pénzt 10 évre 5\%-os kamatozású állampapírba fektetve nem sokkal több, mint 600 ezer Ft lesz a nyereségünk a milliók helyett.)

A leghatékonyabb beruházásnak az egészségvédelmi intézkedések és törvényi szabályozások bizonyultak, melyek gyakran nemzeti szinten, egyszeri alkalommal történtek meg (pl.: védőoltások gyermekkori betegségek ellen, adómódosítások). A legalacsonyabb megtérüléssel legtöbbször az egészségfejlesztési, szélesebb körű, sokrétű, erőforrásigényes és hosszan fenntartandó ténykedések zárultak.

Némely intézkedés kifejezetten veszteséges volt, mint például az egyik tanulmányban az egészséges dolgozók influenza elleni védőoltása (bár tény, hogy e téren kimagasló eredmények is születtek, jelentősen függve az adott évi vakcina hatékonyságától). Ugyanakkor az egészségvédelmi intézkedések közel 35-40-szeres megtérüléssel zárultak. Az egészségfejlesztés esetén - kutatásonként eltérő közepes értékkel - 2-14 körüli megtérülés, illetve költséghaszon arány volt várható.

A helyi népegészségügyi intézkedések bár közgazdaságtani szempontból még mindig nyereségesek voltak, azonban fele vagy negyed akkora volt a gazdaságosságuk, mint a nemzeti szinten végrehajtott intézkedéseknek.

Összességében elmondható, hogy a legtöbb népegészségügyi célú intézkedés költséghatékony. A szerzők felhívják a figyelmet arra, hogy ha az Egyesült Királyság a gyógyításra további 13.000 fontot fordított volna, akkor az a becslések szerint egy QALY-t (minőséggel korrigált életévet), azaz mintegy 60.000 fontnyi nyereséget eredményezett volna, ami csupán 3,16-szoros megtérülést jelentene.

$\mathrm{Az}$ is elgondolkodtató, hogy a brit költségvetés a közelmúltban indítványozott 200 millió fontos megszorítása e téren a legszűkebb becslés alapján is
1,6 milliárd font veszteséget fog eredményezni az állam számára. Vagyis a végrehajtott „gazdaságossági megtakarítások" valójában hibás közgazdasági megközelítést takarnak a hosszabb távú költségvetésben.

Mindez annak tükrében még hangsúlyosabb, hogy az Egyesült Királyság a gyógyító tevékenységre hatalmas összegeket fordít, mely pont azáltal lehetne csökkenthető, hogy a megelőzéstől nem elvonnának, hanem további összegeket invesztálnának.

$A z$ is izgalmas kérdés, hogy van-e más olyan befektetés, mely 5-15 év alatt átlagosan 8-15-szörös megtérülést eredményez, amikor közgazdaságtani szemszögből már az éves 10\%-os haszon is megfelelőnek mondható.

A szerzők megállapítása szerint cikkük korlátait képezi, hogy csak angol nyelvű publikációkat elemeztek, illetve azokat a kutatásokat kizártak, amelyek az Egyesült Királyság egészségügyi rendszerére nehezen lettek volna átültethetők, értelmezhetők (például számos USA-beli tanulmányt). Továbbá csak olyan intézkedések hatásait vizsgálták, ahol emberek csoportjai képezték a beavatkozások célját.

\section{ÖSSZEFOGLALÁS}

Ahogy azt már korábban is sejtettük, a primordiális és primer prevenciós (vagyis a betegség kialakulásának megelőzését, az egészség megtartását célzó) intézkedések nemcsak a lakosság egészségére nézve pozitív hatásúak, hanem a gazdaságra is. Ahogyan e cikk szerzői is megfogalmazták, a legtöbb kormányzat választási ciklusokban gondolkozik és olyan területekre összpontosítja anyagi erőforrásait mely gyorsan, látványosan megtérül azzal a nem titkolt céllal, hogy minél több szavazatot szerezzen. A népegészségügy nem ilyen. Rövid távon nem látványos, nem hoz sok szavazatot. Ahogy azonban számos jó példa mutatja több európai ország esetében is a politikai szereplők összefogásával, a gazdaság hosszú távú érdekeinek szem előtt tartásával az egészség a legjobb, legjövedelmezőbb „befektetés". Mindamellett, hogy a legkifizetődőbb - a jelen kutatás eredményei alapján - a nemzeti színtér mellett a helyi kezdeményezések is többszörös megtérüléssel zárulnak. 
Bár jelenleg egy új fertőző betegség tartja lázban a világot, melynél a primer és még inkább a primordiális prevenció vizsgázik, ne feledkezzünk meg róla, hogy csak hazánkban évente közel 9 ezren halnak meg csak tüdőrákban, melynek $80 \%$-a (évi
7000 fő!) a dohányzás elkerülésével megelőzhető lenne. Nem is beszélve a nagyrészt szintén megelőzhető, évi 65 ezer magyarországi áldozatot követelő keringési rendszer okozta halálozásról!

\section{TANULSÁGOK A HAZAI SZAKEMBEREK SZÁMÁRA}

Amíg keseregve várnánk, hogy lassan fél évszázados késéssel mi is elkezdjük az Észak-Karélia projekt' magyar megvalósítását, merjünk bátran kis lépéseket is tenni. És bár a nemzeti szintű beavatkozások a legkifizetődőbbek, merjünk helyi szinten, akár kis közösségekben is kezdeményezni, hiszen minden „egy unciányi megelőzés felér egy font gyógyítással" (Benjamin Franklin)!

\footnotetext{
i Az Észak-Karélia projekt Finnország 1972-ben indított, hosszú távon rendkívül sikeres, átfogó betegségmegelőzési népegészségügyi programja, amely elsősorban a szív- és érrendszeri halálozások és megbetegedések csökkentését eredményezte, például az egészséges élelmiszerek jelentős ártámogatása, illetve potenciálisan káros élelmiszerek jelentős adóemelése révén.
} 